\title{
No Feeling vs Depth Feeling Journalisms: A Critical Review of the Political Interest Dominance over Principles of Journalism in News and Information on Television in Indonesia
}

\author{
Bambang Winarso \\ University of Prof. Dr. Moestopo (Beragama) \\ Jakarta, Indonesia \\ bbwinarso@dsn.moestopo.ac.id
}

\begin{abstract}
This research focusses on the phenomenon of violation to journalistic principles that is the development of "no feeling journalism" in news and information broadcasting on television. This study analyzes the practice of journalism which is dominated by political interest of media owner who are also politicians which then followed by their staffs in the field. Besides that, the violation to the code of ethics and the code of conducts seem let to happen, and the society become permissive, sceptical, and don't care to what the media did in their broadcasting. This descriptive analysis use Phenomenology phylosophy of Edmund Husserl and Alfred Schutz, or other phenomenologists, also other relevan theories. Analysis also use broadcast regulations, Kovach \& Rosentiel's journalism elements, and Code of Conducts \& Broadcast Programme Standard from the Indonesian Broadcasting Commission (KPI), also personal documentary of interview with informen, field observation, literature study, and online study. It is difficult to differ between a campaign programme, a public service announcement, and political advertisement which is done by the media and its owner. Our broadcasting world has no "qiblah" or welldefined direction of broadcasting, so that presentation, programme content, and the talents tent to disobey the regulation. Violation to regulations have already been warning and given administration sanction to the station according to the KPI and Board of the Press's authorities.
\end{abstract}

Keywords: No feeling journalism; Depth feeling journalism; Violation; Journalistic principles; Qiblah

\section{Introduction}

Indonesia has experienced various ups and downs of political life since its independence in 1945. Each era provides space for the community according to the country's applicable political system at the time. The political system of a country affects the rights of the citizens to express their freedom of opinion, expression, and creativity [14]. The mass media, particularly the broadcasting media, was originally only regulated by the regulation or decree of the Minister of Information, and then regulated by the Broadcasting Act No. 24 Year 1997. The euphoria came after the law was no longer valid and replaced by Broadcasting Act No. 32 Year 2002. The law states that the freedom of expressing opinion and getting information through broadcasting is an embodiment of human rights in the society, nation and country. However, it must be carried out responsibly, harmoniously, and in balanced between freedom and equality in exercising the right based on Pancasila and the 1945 Constitution of the Republic of Indonesia. In addition, the law also states that radio frequency spectrum is a limited natural resource and a national asset that must be preserved and protected by the country and utilized for the welfare of the citizens in accordance with the ideals of the Proclamation of August 17, 1945. 
Regarding the freedom of the press or the speech, primarily through broadcasting mass media, the tendency in interpreting the meaning of freedom in question is barely controlled. It can be observed that the content and the language in broadcasting often do not correspond to the reference in the broadcasting act. The ownership of television broadcasting stations affects the broadcasting content in accordance with the business and political ideology [5-7]. The broadcasting license granted to the legal entity managing television broadcasting is a mandate of legislation, where frequency-spectrum is a limited public domain. However, in the real implementation, there are many real irregularities. It can be seen that television is used for personal or group interests. Hence, it is defined as No Feeling Journalism or Unsympathetic Journalism. It refers to the principles of journalism that are not implemented as stipulated in the law on broadcasting, government regulations, and other regulations.

Because of television's profound influence in the formation of public opinions, attitudes, and behavior, it is necessary for the business actors of broadcasting to comply with all applicable provisions in the existing regulations in the Broadcasting Law, Government Regulation, P3SPS, and other related regulations. In the practice of journalism on television, i.e. a talk show, it can be seen that the dominance of particular party's interests is quite obvious. There are some parties who are prominent or superior (affirmative), giving rise to the perception of sympathy or empathy, or associative with similar roles of hero or a good person. On the other hand, there are "negated" people or parties who are considered as the political opponents of the media owners or groups. Therefore, there is a need to review the assumptions of agenda setting and framing of news/information in television qualitatively to get clarity of the occurrence of the phenomenon.

Therefore, this study presents no feeling journalism versus depth feeling journalism, critical review of dominance of political interest over principles of journalism in news and information on television. In summary, the contribution of this work is summarized as follow:

a. We present a critical review of the political interest dominance over principles of journalism in news and information on television which is based on no feeling vs depth feeling journalisms.

b. We examine the underlying motives of such violation that ignores journalistic principles as stipulated in the laws and government regulations and other relevant regulations.

The rest of this paper is organized as follow. Section 2 presents The Concept of Broadcasting System and Mass Media. Section 3 describes research finding including Theoretical Framework and Hypotheses. Section 4 concludes this work.

\section{The Concept of Broadcasting System and Mass Media}

The theory of Agenda Setting proposed by McCombs and Shaw in [8] describes how great the influence of media is, associated with the messages conveyed to the audiences, namely the actual issues. The media will focus on issues it deems important and often ignore other things that are actually needed by the community. Something considered important by the media will be broadcast repeatedly, either with the similar format or modified variations. The theory of Agenda Setting is the process of media effect or mass communication effect on society. The theory illustrates the power of media's influence on the formation of public opinion, mainly against a repeatedly-broadcast issue.

Framing Analysis by Entman, et al in [9] or Pan and Kosicki in [10] describes the selection process and highlights certain aspects of the real condition of the media, as well as places information in a typical context so that a particular issue gets a bigger allocation than other issues. Framing Analysis basically belongs to the paradigm of constructionism, where reality is not scientifically created or given by the Lord, but shaped and constructed, so that what is presented on the screen might be affirmed and negated. 
Entman in [9] defines the concept of framing as a selection process of various aspects of existing reality to make an event or an issue more prominent in a text of communication. Thus, in many ways, it means particularly presenting the definition of the problem, interpreting the causality, evaluating the moral, and offering a solution to the said problem [11].

Some government regulations (PP) stipulate broadcasting, among others: (PP) No. 11 Year 2005 on Public Broadcasting Institution (LPP), PP No. 12 Year 2005 on LPP of Radio Republik Indonesia (RRI), PP No. 13 Year 2005 on LPP of Televisi Republik Indonesia (TVRI), PP No. 49 Year 2005 on Guidelines for Coverage by Foreign Broadcasting Institution (LPA), PP No. 50 Year 2005 on Broadcasting Implementation by Private Broadcasting Institution (LPS), PP No. 51 Year 2005 on the Broadcasting Implementation by Community Broadcasting Institution (LPK), and PP No. 52 Year 2005 on the Broadcasting Implementation by Subscription Broadcasting Institution (LPB).

In the competitive (commercial) system, i.e. private broadcasters, the ownership is private, both individual and corporate legal entities. The finance entirely comes from advertising and sponsorship revenue. The broadcasting purposes are business-minded, profit-making, and to reach as many audiences as possible. The programs focus more on entertainment and information, or are dominated by entertainment, or by news/information with "counter programming" and "stripping" as the programming strategy.

Television broadcasting in Indonesia at present is dominated by commercial/competitive broadcasting system, with a ratio of ten national commercial broadcasters and one national public broadcaster with TVRI stations in regions/provinces. Commercial broadcasting system tends to be business-minded and profit-making, where the media owner is in full control of the direction and policies of the broadcasting, so that the opportunity is taken for private and group's gain. It leads to a conflict of interest, between the use of the mass media as a public sphere to meet the desires and needs of the community and the use of mass media for political purposes of the owner and group. The owner who has been involved in politics as politician from the beginning will eventually utilize his mass media to support his political purpose. At this stage, the functions of mass media as stipulated in the legislation are often neglected.

According to Ardianto in [12], the function of television is the function of mass media, namely: the function of information, education and entertainment. The function of information explains that television is a medium capable of broadcasting quite satisfying information. This is due to two factors: "Immediacy and Realism". Immediacy includes the notion of direct and close. The events broadcasted on television can be seen and heard by audiences at the time of the event, as if they were in the place where the events take place. Realism implies reality, where a television broadcasts audio-visual information in accordance with the facts based on reality. The function of education, i.e. public knowledge and reasoning, explains that television broadcasts particular occasions contain education implicitly such as films, quizzes, and etc. called Educational Television (ETV), an educational program inserted in the general program. Due to its potential, the function of education contained on television is often named long-range educational means called Instruction Television. The function of television as a medium of entertainment is very dominant. Most of broadcasting time is filled by entertainment programs. This is understandable because television can display live images and sound, and can be enjoyed even by audiences who do not understand a foreign language, or even by illiterate audiences.

Reform era has emphasized the other functions of television, namely the function of promotion and social control. The function of promotion does not only include the promotion of goods and services in the form of commercial advertising and public service announcements, but also the promotion of ideology wrapped in political advertising either overt or covert ones. Technological advancement in information and communication 
allows direct interaction between communicators (senders) and receivers through television broadcasting.

Reality of the practice of journalism shows the imbalance in broadcasting news or information in accordance with the business or political interests of the media owners. Even though the law has regulated objectivity, independence and neutrality of the media, in reality it is often far from what it is supposed to. Articles in the Broadcasting Law, Code of Ethic of Journalism, Code of Conduct of Broadcasting (P3) and Broadcasting Program Standards (SPS) are often neglected for the interests of the media owners. Objectivity and neutrality are expensive and difficult to obtain. According to Westerstahl [13], a political scientist from Sweden and McQuail in [14], objectivity has two dimensions, namely factualness and impartiality. Factualness refers to a form of news or event coverage and statements that are free from opinion or comment. Factualness refers to the search for truth, for example in the completion and the accuracy of news report by checking on independent sources and precision, all is intended for quality information rather than a wrong or suppressing opinion. Furthermore, factualness is also associated with the "relevance" sub dimension. Relevance is more difficult to define or to achieve objectivity, but it is as important as the search for truth. According to Nordenstreng and Brown in [15], relevance is more related to the selection process rather than formation or presentation. Clear and crystallized principles of selection are necessary for the sake of potential audience and the wider community. Basically, the information conveyed will have an effect either within a short time or a long time, therefore, it is better for the information to be beneficial for the audience. Impartiality consists of two sub dimensions, namely balance and neutrality. Impartiality refers to the adoption of a neutral behavior for reporters in delivering news/information by eliminating personal interests or subjectivity and hidden agenda. It is difficult for journalists to get on the proper relevance, mainly because of the pressure and constraints in the newsroom. In fact, the determination of the relevance comes from "above", about matters that interest public, delivered to the involved guest or resources, according to the objectives of the program or the version of the producer.

Impartiality should be achieved through a combination of balance/non-partisan and neutral/ neutrality in the presentation of news and information. Balance means equality or proportionality among time, space, and emphasis on the delivery and presentation of the material. Neutrality requires the presentation of interpretation and an impartial point of view. Neutrality should not affirm only one party and negate the other. The author elaborates the scheme using the scheme source of Westerstahl in [16] as depicted in Figure 1 as follow: 


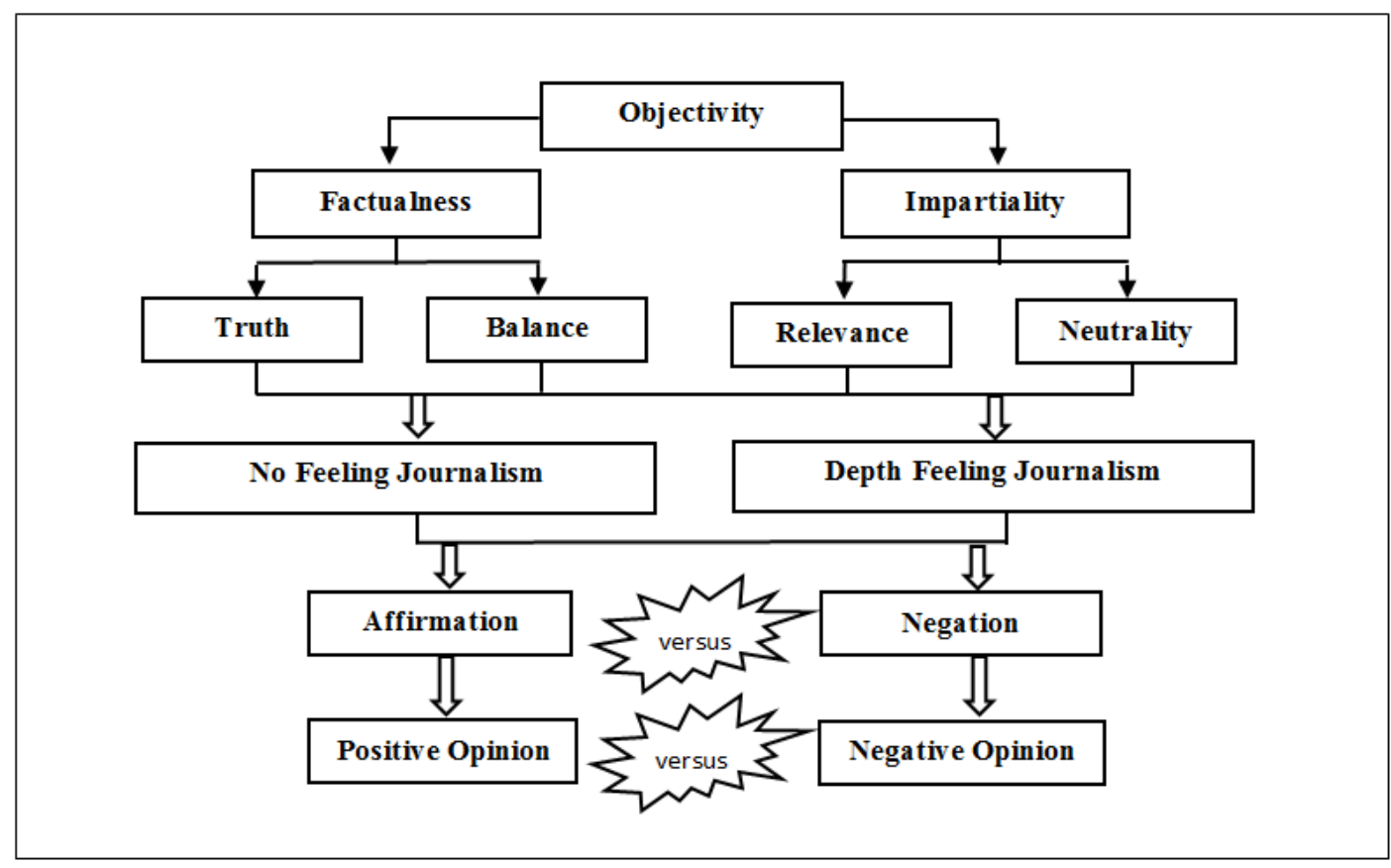

Figure 1. Theoretical Framework

From Figure 1, hypotheses are built for research purposes, intended as a framework for the author during the process of collecting and processing data.

- The factor encouraging television as broadcasting media to ignore the principles of journalism in broadcasting news and information resulting in the practice of "no feeling journalism" or unsympathetic journalism versus "depth feeling journalism" or sympathetic journalism is the dominance of political interests as well as economic interest of the media owners to achieve certain goals.

- The community considers the tendency toward the practice of no feeling journalism and the disregard of journalism principles in broadcasting the news and information on television as something very powerful, trust-abusing, and ultimately permissive.

- The sanction given by the authorized press and broadcasting institution to the no feeling journalism in television broadcasting station is only just a warning, a reprimand, or a threat. There is no court action resulted in the revocation of the broadcasting license.

\section{Results and Discussion}

In this section, we present the research finding and following by discussion.

\subsection{The Ownership of a Mass Media According to the Law}

The ownership of a mass media is regulated in Broadcasting Act No. 32 Year 2002 for public broadcasting services, private broadcasting services, community broadcasting services, as well as subscription broadcasting services. Article 14 regulates the Public Broadcasting Institution (LPP). LPP is a broadcaster in the form of Indonesian legal entity established by the country. It gives service to the public interest in independent, neutral, and non-commercial manner. Article 16 of Act No. 32 Year 2002 on Broadcasting regulates Private Broadcasting Institution (LPS). LPS is a non-commercial broadcasting institution whose scope of business is just to run radio or television broadcasting services. Article 17 (1) states that LPS is established whose entire initial capital is owned by Indonesian citizens and/or legal entity. Paragraph (2) states that LPS can do addition and 
development in order to meet the capital coming from foreign capital, no more than $20 \%$ (twenty percent) of the total capital and owned by two shareholders in minimum. Paragraph (3) states that LPS needs to provide the opportunity for the employees to own shares of the company and to give the company a share of profit. Article 18 Paragraph (1) through (4) regulates LPS as follows: The concentration of the ownership and control of LPS by one person or legal entity, either in one or in several broadcasting areas is restricted. The cross-ownership between LPS providing radio broadcasting services and LPS providing television broadcasting services, between LPS and print media companies, as well as between LPS and other LPS, either directly or indirectly, is restricted. The amount and coverage of local, regional, and national broadcasting areas, both for radio broadcasting services and television broadcasting services are prepared by the Indonesian Broadcasting Commission (KPI) together with the Government.

Community Broadcasting Institution (LPK) is regulated under Article 21 to Article 24. Article 21 states that LPK is a broadcaster in the form of Indonesian legal entity, established by a particular community, independent and non-commercial, with a low transmission, limited coverage areas, whose purpose is to serve the interests of the community. Community Broadcasting Institutions as referred to in paragraph (1) should: be nonprofit, not be a part of a for-profit company; educate and advance the community in achieving prosperity by implementing programs that include culture, education, and information describing the identity of the nation. Article 22 states that LPK is funded by the contribution of a particular community and owned by the community. The source of funding can be gained from donations, grants, sponsorships, and other legitimate and nonbinding sources. Article 23 states that LPK is prohibited to receive initial funding to establish and operational funding from foreign parties. The LPK is prohibited to broadcast advertisements and/or other commercial broadcasts, except for public service announcements. Article 24 states that LPK is obliged to make the code of ethic and conduct to be known by the community and other communities. In the event of a complaint from the community or other communities regarding the violations of the code of ethic and conduct, LPK is obliged to take action in accordance with the applicable guidelines and regulations. Subscription Broadcasting Institution (LPB) is regulated in Article 25 to 27 of Act No. 32 Year 2002 on Broadcasting. LPB is a broadcaster in the form of Indonesian legal entity, whose scope of business is only to provide subscribed broadcasting services and is required to get subscription broadcasting license beforehand. Observing the rules on LPS in Article 18, it is obvious that there are restrictions on the ownership and control of LPS by one person or legal entity, either in one or in several broadcast areas. Furthermore, there are restrictions on cross-ownership between LPS providing radio broadcasting services and LPS providing television broadcasting services, between LPS and print media companies, as well as between LPS and other LPS, either directly or indirectly. PP No. 50 Year 2005 Section V sets restrictions on the ownership and control as well as cross-ownership. The ownership, control, and cross-ownership of media are very crucial and difficult to manage.

\subsection{The Ban on Monopolistic Practices}

In an authoritarian system, the control of broadcasting is a government monopoly. Monopolistic market may occur in the print media (newspapers) and Cable TV. Cable TV system utilizes franchising, where each operator manages cable TV system in specific areas, particularly for Community Antenna Television (CATV). Cable TV system with MMDS (Multichannel Multipoint Distribution Service) system is also monopolistic, because MMDS is usually preferred for areas called blank spot area. The SMATVS or Satellite Master Antenna Television System, or commonly referred to as private cable, is routed through a small cable to the flats or rooms of the customers. With such system, it is only operated by one operator, and the customers can freely choose the desired channel or program. 
According to the author's personal note as a Member of the Team of Formulation and Drafting of Broadcasting Law which was then ratified into Law No. 24 Year 1997 on Broadcasting (The Law compiled over 19 years was no longer valid with the presence of Law No. 32 Year 2002 on Broadcasting), the Team had conducted a comparative on the setting or restriction of the broadcast range in other countries including the United States, France, Australia, and many others. In general, there were restrictions on the range of the number of people covered, about 25 percent in maximum. Later, Draft Law on Broadcasting Year 1997 was formulated with the broadcast range covered up to 50 percent of the population. It was approved by the House of Representatives; however, when it was submitted to President Soeharto to be enacted, the President returned it by reasoning that the broadcast range should not be limited. Let the market determines their choice. Since then, the discourse of unfair competition and a race to monopolize the broadcasting market share by powerful investors emerge. Even though the Act No. 24 Year 1997 was later replaced by Act No. 32 Year 2002, its elaboration in PP No. 50 Year 2005 still provides an opportunity for the occurrence of monopolistic practices. Moreover, law enforcement is not running properly. KPI has its authority dulled because of the decision of the Constitutional Court No. 005/PUU-I/2003 annulling several articles about the authority of KPI. Judicial review is filed by several organizations, namely: Indonesian Television Journalists Association (IJTI), National Association of Private Radios of Indonesia (PRSSNI), Indonesian Advertising Companies Association (PPPI), The Association of Indonesian Television Broadcasting (ATVSI), Indonesian Dubbing Association (Persusi), and Indonesian Television Community (KOMTEVE), represented by the attorney of Lubis in [17].

\subsection{The Broadcast Network System}

The provisions in laws or government regulations are often ambiguous and overlapping between a rule and another, so that business actors will look for weak points in the regulations and possible opportunities for them to do something for their benefit and interests. The possibility or opportunity exists in Article 34 of PP No. 50 Year 2005 on the Broadcasting Implementation by Private Broadcasting Institution (LPS), regulating Network Station System. Observing the rules in Article 34 and 36 of the PP, it is clear that the business actors of the television broadcasting feel restricted to reach out to as many provinces in Indonesia. Television stations that already cover more than 75 percent of the total of provinces before the rules are enacted have no problem with the affiliate system. However, the number of private television stations in each province is limited so that not all nationwide stations will get affiliate partners in specific areas. Therefore, the competition to get a partner particularly in provincial areas with high population density will be very tight, leading to unfair competition. The application of broadcasting license by the private sector requires the draft of the proposed business including the plans to build at least one transmitting stations each in the west, central, and east part of Indonesia.

\subsection{The Political Maneuver of Media Industry}

In the broadcasting world, the political maneuver will occur naturally. However, it is usually preceded by economic maneuver to strengthen the position, the image, and the cash flow, so that the broadcasting can keep airing. Operational funding for production and broadcasting of commercial television is entirely obtained from the advertising revenue and sponsorship. If the target of the revenue is not met, the expenditure (the cost of program production, the cost of broadcasting, rental equipment, the provision of new equipment and spare parts, the cost of marketing and promotions, employees' salaries, guarantees/benefits of management and employees, taxes, debt, and others) will burden the management. Therefore, the owner as the manager of television broadcasting media 
will develop any business of his that can be related to the broadcasting system. The crosssubsidies will occur when the operational costs of the broadcast are not fulfilled.

Television as audio and visual media gives bigger influence than other mass media. Although the era of politics has passed, the shadows of partisan journalism still exist. When a political party is over, some people even consider that the next political party has just begun. When the old political party has entered a period of conclusion due to the exhaustion caused by the previous political fight, new parties will emerge. The recess of the old party is being used by politicians to enter their television to spread their new ideology. What the media owners want and discourse will be supported by all their employees without exception as a form of loyalty. Another option is for the employees to resign from the company. Political maneuver can occur in many forms, among others: through broadcasted speech or monologue about something as if it is a very important matter, that in fact it is an affair only for the government. In addition, charity, donation (in small amounts), visit to the community (mainly to those under the poverty line and those whom require attention), party meetings, and others, are broadcasted in straight news or feature and documentary, as padding/filler, talk show, or running text. Political maneuver becomes politicized mass media, inviting the audience to enjoy episteme or third simulacrum, and persuading the community to live in a false happiness. Based on the author's observation, the new orders in the broadcasting media, particularly television, have evolved into a kind of popular culture or mass culture, where people will be very happy and proud when their face appears on television. Television has become a medium for someone to exist, particularly for intellectuals, and finally into the fields of personal promotion. The new orders in the broadcasting world are not only regulated by external regulations (legislation), but also by internal rules, namely the policy and direction of each broadcasting station. In this context, when the practice of no feeling journalism emerges and dominates its program, disregard for human dignity as well as disregard for the proper journalism will happen.

According to Sobary in [18], when the new orders has become a "media agenda", there are two important things difficult to obtain or even almost non-existent, namely "public accountability" and "qiblah" of broadcasting.

The "qiblah" of broadcasting is almost non-existent since it is associated with attitudes and values. Television nowadays only provides matters to laugh at people, low jokes (low taste sensation, according to Nugroho in [11]), discusses one's personal disgrace, or degrades the dignity of political opponents. These happen due to the shift of modesty, values, and perspectives. Sobary states that the managers of television should build the interest and the taste of life. Television should not only play a role in its function as a medium of entertainment and information, but also the role of education and social control. In relation to social control, it should use its own perspective in accordance with its editorial policy.

Managing the media is like combining two difficult things, between idealism and business. How about the values of the manager of the media who can achieve his economic achievement? Television mostly provides worldly matters only. According to Sobary in [18], the values are an impossibility to be brought into the political broadcast, or other broadcasts. The point of view with a high taste, depth feeling or sympathetic rather than no feeling or unsympathetic, will be able to direct the "Qiblah" of our broadcasting. Here is a snippet of an interview the author with Sobary in [19] (Jakarta, 0207-2010).

"If changing the orders in broadcasting is performed by authorities in communication, it will be embraced. Now, broadcasting is only about good image and money. It cleverly deceives the public with the image rather than the person directly in the talk shows, infotainment, and other broadcasts. A person can talk a little bit naughty, with intimacy or with a smile, not only keep up his image. It flatters another country. That is a devotee 
and an admirer of image or shadow. Good looking is just good looking. It is a nonsense given by the television or media. However, we cannot avoid this.

$Y e s$, they reconstruct reality to create a new image, life, and phenomenon. This is what I learned from an individual named Sukanto SA, a writer, a poet, an author of children's stories. Even though the era has shifted, I think it is still relevant to us. According to him, recreating social life, image, or other things, is building a new world. The new world is similar as the world that we use in short stories.

What is used in the short story is similar with what is used by journalists to be presented in television through images. The source is similar, that is, life. There are many variations. From a wide variety of life, there is an "angle" that I see as a writer of short stories, that I will bring in the new world in the form of short stories. However, surely I will not only just transfer it. There is nothing aesthetics and novelty in that, and it certainly won't inspire."

Those are the opinions by Sobary in [19] as an observer of culture, who is furious with the state of television broadcasting in the recent decade. As a former Chairman of Antara News Agency, Sobary in [19] says that maybe we are being negligent, but we are not supposed to be negligent all the time nor that all of us or the whole nation can be negligent in the same time.

\section{Conclusion}

What happened to the world of journalism in Indonesia today is a reflection of the political state of this country, where the politicians dominate the mass media, particularly television, to achieve personal or group's purposes. The phenomenon of the commercialization and politicization of the mass media and also a market system of oligopolistic media industry, that is prohibited and also limited by the law, happens naturally or due to technological advances. Oligopoly system allows the mass media market to be dominated by several business groups only. Because of the ownership of two or more television stations and cross-ownership with other media such as radio stations, newspapers, cable television, and online media, monopoly over the information market will automatically happen. The control of the mass media is a vessel for achieving the desired political power. The development of no feeling journalism and disregard of depth feeling journalism is caused by the politicization of television for certain purposes. According to the theory of Agenda Setting and Agenda Media, the manager of the mass media shapes the market for the purpose of imaging, and others. The dominance of the political interests over the principles of journalism, particularly in broadcasting news and information such as talk show, is framed according to the vision and mission of the media owner and followed up by the executor in the field, so that the format of the program, the topic or the content, and the speakers are those with similar ideology. The community has the right to complaint this untruth through authorized institutions, or directly to the person concerned through any media. The broadcasting media is used as a political machine to reach the pinnacle of power. It shows that the freedom to use media, expression, speech, or comment, and the freedom of the market have provided opportunities for intellectuals to take advantage of the mass media as a means to make him and his group exists. It can give positive effect on the community, but also give the negative effect on the community.

Quoting Sobary in [19], there has been a change in worldview (perspective), values, and attitudes towards life and living in the community, giving birth to the new orders including the orders in the broadcasting media. The orders of media are set up by the capitalists for their own political interests. Our broadcasting has no "qiblah", because there is no life essence or inner essence. In using media, there should be social world of individual and inner essence. The inner essence should be the "qiblah" of our broadcasting. The qiblah is the living university. A journalist needs morality and the essence of life in dealing with his station and its code of ethic and code of conduct, with the public that needs him. 


\section{Acknowledgement}

This research is supported by Universitas Prof Dr Moestopo (Beragama), Jakarta, Indonesia.

\section{References}

[1] K. D. Jackson and L. W. Pye, "Political power and communications in Indonesia. Univ. of California Press", (1978).

[2] E. Aspinall and G. Fealy, "Local Power \& Politics in Indonesia: Decentralisation \& Democratisation", ISEAS-Yusof Ishak Institute, (2003).

[3] J. R. Bowen, "On the political construction of tradition: Gotong Royong in Indonesia", The Journal of Asian Studies, vol. 45, no. 3, (1986), pp. 545-561.

[4] B. Anderson, "Language and power: Exploring political cultures in Indonesia", Cornell University Press, (1990).

[5] E. Hollander, L. d'Haenens and J. Bardoel, "Television performance in Indonesia: steering between civil society, state and market", Asian Journal of Communication, vol. 19, no. 1, (2009), pp. 39-58.

[6] A. Sudibyo and N. Patria, "The television industry in post-authoritarian Indonesia", Journal of Contemporary Asia, vol. 43, no. 2, (2013), pp. 257-275.

[7] P. Kitley, "Television, nation, and culture in Indonesia", Ohio University Press, (2014).

[8] McCombs, M. E., \& Shaw, D. L. (1972). The agenda-setting function of mass media. Public opinion quarterly, 36(2), 176-187.

[9] Entman, R.M., 1993. Framing: Toward clarification of a fractured paradigm. Journal of communication, 43(4), pp.51-58.

[10] Pan, Z. and Kosicki, G.M., 1993. Framing analysis: An approach to news discourse. Political communication, 10(1), pp.55-75.

[11] Nugroho, Bimo, 1999. Politik Media Mengemas Berita. Jakarta: Institut Studi Arus Informasi.

[12] Ardianto, E., Komala, L., \& Karlinah, S. 2009. Komunikasi Massa: Suatu Pengantar. Bandung: Simbiose Rekatama Media.

[13] Westerståhl, J. (1945). Svensk fackföreningsrörelse: organisationsproblem, verksamhetsformer, förhållande till staten (Doctoral dissertation, Tiden).

[14] D. McQuail, "Mass Communication Theory: An Introduction”, London: Sage Publications, (1992).

[15] K. Nordenstreng and A. Brown, "Inventory of textbooks in communication studies around the world", Javnost-The Public, vol. 5, no. 1, (1998), pp. 79-89.

[16] J. Westerståhl, "Objective news reporting: General premises", Communication research, vol. 10, no. 3, (1983), pp. 403-424.

[17] T. M. Lubis, "The Rechtsstaat and human rights", Indonesia: Law and Society (The Federation Press 1999), (1999), pp.171-185.

[18] M. Sobary, "Kesalehan dan tingkah laku ekonomi", Yayasan Bentang Budaya, (1995).

[19] "Interview with Mochamad Sobary, Cultural Observer/Humanist, Writer, Media Observer, Social Critic, Former Chairman of LKBN Antara", Language Center of the Ministry of National Education, Rawamangun, Jakarta, (2010). 